\title{
Transport of pollutants from nearby catchments to the Nagarjuna Sagar Dam
}

\author{
S.K. Jha ${ }^{1}$, G.P. Verma ${ }^{1}$, S.S. Gothankar ${ }^{2}$ and V.D. Puranik ${ }^{2}$ \\ ${ }^{1}$ Environmental Assessment Division, BARC, Trombay, Mumbai - 400085 \\ ${ }^{2}$ Radiation Safety Systems Division, BARC, Trombay, Mumbai - 400085 \\ e-mail: skjha@barc.gov.in
}

\begin{abstract}
The understanding of the fate of the various pollutants and its mobility in the catchments of Nagarjun Sagar dam built on the Krishna river is of utmost important .As the Pedaguttu and Lambarpur catchments area has a proposed Uranium mining sites and Nagarjuna Sagar dam is the third largest man made dam which is the ultimate destination of all the rivulets in the Pedaguttu catchments. The concept of the distribution coefficient is invoked to understand the residence time of radionuclide on its nature. Expressions are derived to estimate the value of soil erosion constant using naturally occurring radionuclide. Based on ${ }^{210} \mathrm{~Pb}$ profile in the sediment core, the sedimentary load of $0.24 \mathrm{gm} \mathrm{m}^{-2} \mathrm{y}^{-1}$ was observed in the Pedaguttu and Lambarpur side of the Dam. The retention time and the transport coefficient of the pollutant were further obtained by using the appropriate modeling equation and was found 3776 and $2.7 \times 10^{-5}$ respectively. The comparative exercise of the retention time and transport coefficient was done with the other studied catchments of the world for the further validation of the result.
\end{abstract}

\section{INTRODUCTION}

In order to sustain as well as increase the nuclear power production in India, constant search and exploration of new uranium sources is being carried out. Under this programme, new deposits of uranium at Lambarpur and Pedaguttu located in Pedda Adsarlapalli Mandal of Nalgonda district at a distance of about $135 \mathrm{~km}$ from Hyderabad, Andhra Pradesh, India was found. The area encompassing uranium deposits of Lambarpur and Pedaguttu are drained by river, which ultimately meet the third largest man-made Nagarjuna Sagar dam, Andhra Pradesh, India built on Krishna river (fig 1). The contribution of naturally occurring radionuclide content, made by these outcrops through run off, due to rainwater from catchments of dam would be reflected in the sediment of Nagarjuna Sagar dam. Earlier studies have shown that soil erosion from watershed area and the movement of pollutants in the aquatic system can be quantified with the aid of radioisotopes present in the environment. The behavior of ${ }^{210} \mathrm{~Pb}$ from various sources in the soil surface water system provide the most direct information on the kinetics of process involving Heavy metals from natural and man made sources. For example the fallout ${ }^{137} \mathrm{Cs}$ has been advantageously used by many researchers to quantify the soil erosion, estimating lake sediment age and in probing the transport. In addition to man made ${ }^{137} \mathrm{Cs}$ the naturally delivered radioisotopes like ${ }^{210} \mathrm{~Pb}$ have been successfully used for lake and river sediment [10]. The unique property that makes radioisotopes invaluable in studying aquatic system is the inherent decay constant $\lambda\left(\mathrm{yr}^{-1}\right) \mathrm{which}$ governs the disintegration of the isotope with accurately known rate, which is independently of physical and chemical environment of isotopes. In other words a radioisotope acts as a natural clock whose scale is governed by the $\lambda\left(\mathrm{yr}^{-1}\right)$. However the decay property of a radioisotopes generally stated in terms of half life $\left(\mathrm{t}_{1 \backslash 2} \mathrm{yr}^{-1}\right)$ which is related to decay constant as, $\lambda=0.693 / \mathrm{t}_{1 / 2}$. The ${ }^{210} \mathrm{~Pb}$ having $\mathrm{t}_{1 / 2}=22.3 \mathrm{yrs}$ is used for lake and river sediment dating up to about 100 years old sediment but ${ }^{14} \mathrm{C}$ having $\mathrm{t}_{1 / 2}=5730 \mathrm{yrs}$ is used for the sea sediment dating of up to several thousand years old sediment. 


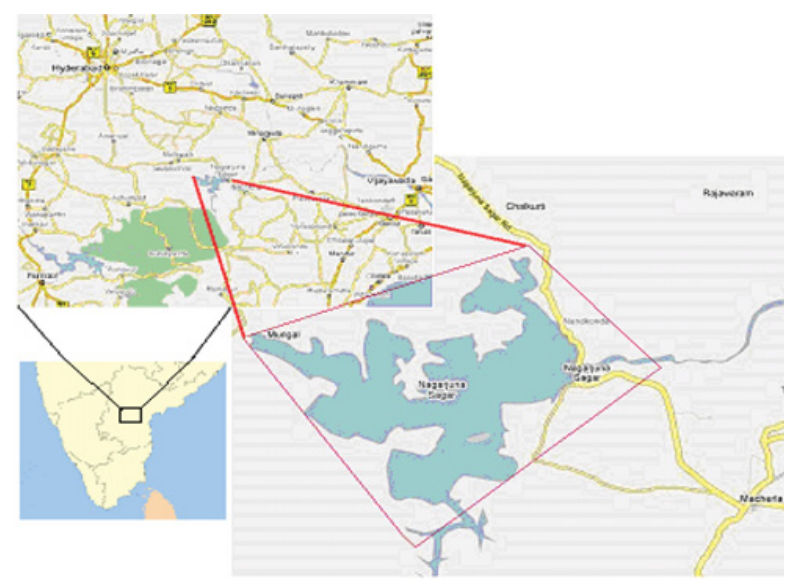

Figure 1. The Location of Nagarjuna Sagar dam in India.

In this work attempt has been made to calculate the residence time of trace element at Catchments based on its reaction with distribution coefficient.

\section{STUDY AREA}

The river Krishna snaking through the hills and forest in full flow is halted only by the Nagarjuna Sagar Dam that irrigates over 100 thousands acres of land. Study area lies in the tropical region where climate is characterized by very hot summer, mild winter and low rainfall. Summer is typically from March to June when temperature varies from $46^{\circ} \mathrm{C}$ during daytime to a minimum of $23^{\circ} \mathrm{C}$ at night. During December also maximum daytime temperature rises to $38^{\circ} \mathrm{C}$ with a minimum $17^{\circ} \mathrm{C}$. The region is characterized by low rainfall recorded at Nagarjuna Sagar dam office. Mean annual rainfall recorded at the IMD observatory at Khammam at an aerial distance of $110 \mathrm{~km}$ is $1086 \mathrm{~mm}$ [5]. Nagarjuna Sagar dam is one of the two main reservoir of the state cater to water need of the Andhra state.

\section{EXPERIMENT}

\subsection{Sample Collection and measurement}

To generate the required data surface soil samples were collected from the catchment's area of the Dam includes the proposed mining area were from locations covering Lambarpur, Pedaguttu and Mallapuram considering the natural drainage pattern through which land runoff meets the dam. Sediment core samples were collected from the Lambarpur side (C1) and Pedaguttu side (C2) of the Nagarjuna Sagar dam. The collection of surface soil and sediment core samples were carried as per the collection procedures described by US, Environmental Measurement Laboratory [EML, 1990]. The detail of sampling locations, preparation and the radionuclide data were published by the (Sangeeta et.al, 2009).

All the samples were homogenized, dried and grinded and stored in polythene bottles. The excess ${ }^{210} \mathrm{~Pb}$ in different core sections was measured by the procedure described by Carpenter et al. [3] and S. K. Jha et al. [8]. Activities of ${ }^{210}$ Po along with the ${ }^{208}$ Po tracer in surface soil and sediment core section were measured by alpha spectrometry on a silicon surface barrier detector connected to a multichannel analyzer. Duplicate analysis of well homogenized sediment samples showed an analytical precision of $8-10 \%$. The spike tracer efficiency was obtained at $70-80 \%$. The quality assurance measurement is assessed through the analysis of certified reference standard IAEA-135 Marine Sediment. The details of methodology are described elsewhere [8]. 


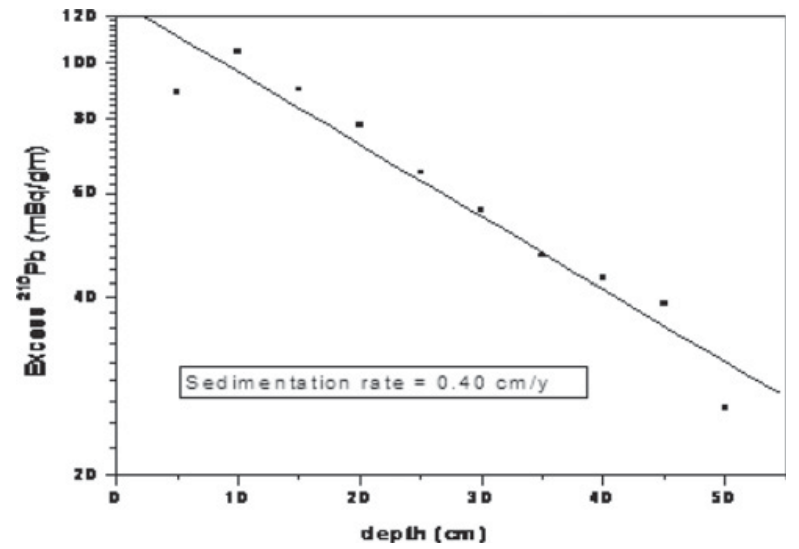

Figure 2. Depth profile of excess ${ }^{210} \mathrm{~Pb}$ in sediment core collection from lambapur site of nagarjun Sagar dam.

\subsection{Calculation of residence}

Let us assume $\mathrm{Ii}(\mathrm{Bq})$ is the radioactive inventory of substance is on an entire watershed area or in aquatic body. Fi $\left(\mathrm{Bq} \mathrm{yr}^{-1}\right)$ amount of the material falling per unit time from the atmosphere on the watershed or on the surface of the aquatic body and $\mathrm{Ki}_{\left(\mathrm{yr}^{-1}\right)}$ is the sum of all type of removal constant, the following material balance equation can be written

$$
\mathrm{dI}_{\mathrm{i}} / \mathrm{dt}=-\lambda_{\mathrm{i}} \mathrm{I}_{\mathrm{i}}-\mathrm{K}_{\mathrm{i}} \mathrm{I}_{\mathrm{i}}+\mathrm{F}_{\mathrm{i}}
$$

In writing the above equation it is assumed that the rate of removal of material can be mathematically represented as $-K_{i} I_{i}$. This assumption brings analogy between $\lambda_{i}$ and $K_{i}$ and consequently and $K_{i}$ plays the similar role. If $\mathrm{F}_{\mathrm{i}}\left(\mathrm{Bq} \mathrm{yr}^{-1}\right)=0$ it is interesting the note that $\lambda_{\mathrm{i}}$ and $\mathrm{K}_{\mathrm{i}}$ can be viewed as decay constants of material $I_{i}$ which is disintegrating at a rate of $\left(-\lambda_{i}+K_{i}\right)$.

Under steady state condition $\mathrm{dI}_{\mathrm{i}} / \mathrm{dt}=0$

And for a radioactive material equation (1) can be written as

$$
\begin{aligned}
0 & =-\lambda_{\mathrm{i}} \mathrm{I}_{\mathrm{i}}-\mathrm{K}_{\mathrm{i}} \mathrm{I}_{\mathrm{i}}+\mathrm{F}_{\mathrm{i}} \\
\mathrm{Fi} & =\lambda_{\mathrm{i}} \mathrm{I}_{\mathrm{i}}+\mathrm{K}_{\mathrm{i}} \mathrm{I}_{\mathrm{i}} \\
& =\mathrm{I}_{\mathrm{i}}\left(\lambda \mathrm{i}+\mathrm{K}_{\mathrm{i}}\right) \\
\left(\lambda \mathrm{i}+\mathrm{K}_{\mathrm{i}}\right) & =\mathrm{Fi} / \mathrm{I}_{i}
\end{aligned}
$$

or residence time $=\mathrm{I}_{\mathrm{i}} / \mathrm{F}_{\mathrm{i}}$

Equation (2) states that removal rate $\mathrm{K}_{\mathrm{i}} \mathrm{I}_{\mathrm{i}}$ is equal to the input rate Fi.

\subsection{Erosion, distribution coefficient model of a watershed}

The model describe the soil erosion and pollutant dissolution is shown in Fig. 3

The model described above contains following three basic components.

1) Diffusion advection transport parameter to account for migration of pollutant deeper into the watershed soil.

2) Erosion constant to calculate soil erosion rate from watershed soil. 


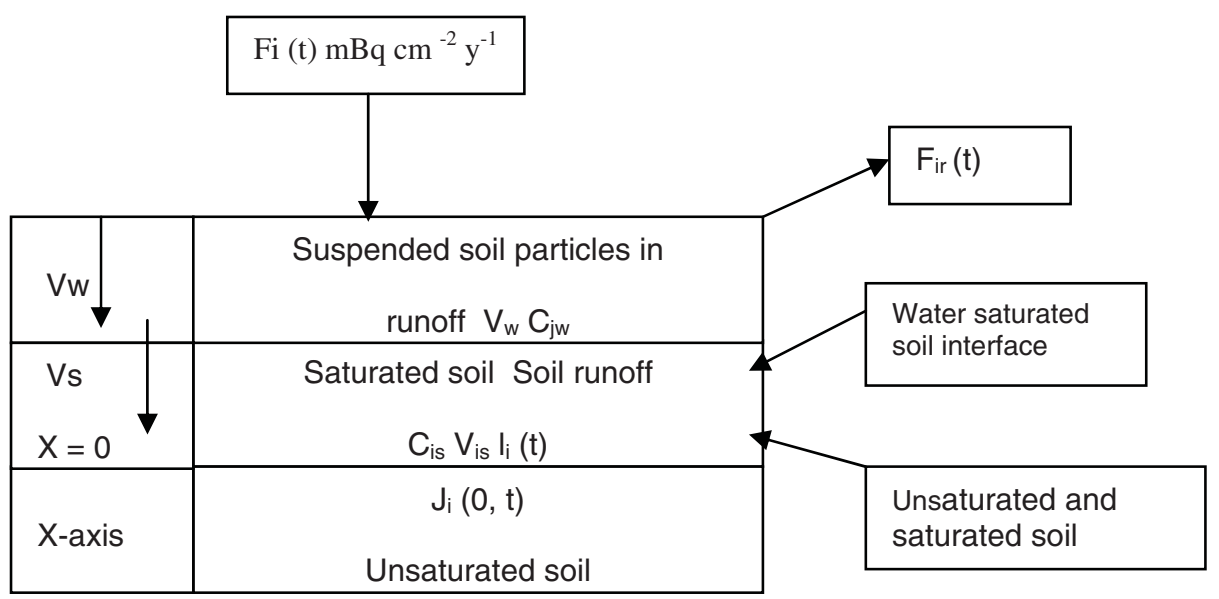

Figure 3. The model describing the soil erosion and pollutant dissolution.

3) Distribution coefficient to quantify the partitioning of pollutant between dissolved and particulate phase.

Model shows $1 \mathrm{~cm}^{2}$ of the catchments on which various processes are occurring as describe below.

Catchments soil receives both the radioactive pollutant $\mathrm{i}$ and the rainfall from atmosphere. Fi(t) $\left(\mathrm{mBq} \mathrm{cm}{ }^{-2} \mathrm{yr}^{-1}\right)$ is the flux of the pollutant $\mathrm{i}$ and $\mathrm{V}_{\mathrm{w}}\left(\mathrm{cm}^{3} \mathrm{~cm}^{-2} \mathrm{yr}^{-1}\right)$ is the annual rainfall on the watershed. The activity being deposited on the watershed get distributed between the rainwater and watershed soil in accordance with the distribution coefficient $\mathrm{K}_{\mathrm{di}}$ (dimensionless)

$$
\mathrm{K}_{\mathrm{di}}=\mathrm{C}_{\mathrm{is}} / \mathrm{C}_{\mathrm{iw}}
$$

Where $\mathrm{C}_{\mathrm{is}}\left(\mathrm{mBq} \mathrm{cm}^{-3}\right.$ of soil granules) is the concentration of the radionuclides, $\mathrm{i}$, in the surface soil of the catchment or watershed and $\mathrm{C}_{\mathrm{iw}}\left(\mathrm{mBq} \mathrm{cm}^{-3}\right.$ of water) is the concentration of radionuclide $\mathrm{i}$ in the rainwater after getting equilibrated with catchments surface soil. It is assumed that the distribution equilibrium is established immediately and $\mathrm{K}_{\mathrm{di}}$ is independent of the concentration of the radionuclide. $\mathrm{V}_{\mathrm{s}}\left(\mathrm{cm}^{3} / \mathrm{cm}^{2}\right)$ represent the volume of the saturated soil zone having the concentration of radioactive pollutant in the soil phase and in the pore water as $\mathrm{C}_{\mathrm{is}}$ and $\mathrm{C}_{\mathrm{iw}}$ respectively. The saturated soil zone has porosity, $\phi$ (dimensionless) and consequently Vs contains $(1-\phi) \mathrm{Vs} \mathrm{cm}^{3}$ of soil and $\phi \mathrm{Vscm}^{3}$ of pore water. Vs is also the vertical depth of the saturated soil at the bottom of which lies the origin of $\mathrm{X}$-axis directing positively downwards into soil. The presence of contaminant, $\mathrm{i}$, in the volume Vs i.e. the region $\mathrm{Vs}<\mathrm{x}<0$ is as a result of mixing of contaminant, rainwater and soil about the presence of contaminant in the region $\mathrm{x}>0$ is due to downward transport of contaminant by diffusion and advection. The diffusion advection flux at $\mathrm{x}=0$ is shown by the symbol $\mathrm{J}(0, \mathrm{t})$ at $\mathrm{x}=0$ lies the interface between saturated and unsaturated soil with respect to water. At $x=-V s$ lies the interface between saturated soil and the rainwater containing the contaminant both in the dissolved and particulate phase. The particulate phase in the rainwater is due to erosion of soil from watershed. If $\mathrm{Ec}\left(\mathrm{cm} \mathrm{yr}^{-1}\right)$ is the erosion rate of the watershed soil, the quantity of radioactivity of pollutant being removed by soil erosion is

$$
\operatorname{Ec}(1-\phi) \mathrm{C}_{\mathrm{is}}\left(\mathrm{mBqcm}^{-2} \mathrm{yr}^{-1}\right)
$$

Thus total quantity of the activity associated with rainwater both in dissolve and particulate phase is

$$
\mathrm{C}_{\mathrm{iw}} \mathrm{V}_{\mathrm{w}} \eta+\mathrm{Ec}(1-\phi) \mathrm{C}_{\mathrm{is}}
$$

Where $\eta$ represents the fraction of rainfall as runoff. 

as

The $\mathrm{F}_{\text {ir }}(\mathrm{t}) \mathrm{mBq} \mathrm{cm}^{-2} \mathrm{yr}^{-1}$ is the flux going out from the watershed to a river or dam can be written

$$
\mathrm{F}_{\mathrm{ir}}(\mathrm{t})=\mathrm{E}_{\mathrm{c}}(1-\phi) \mathrm{C}_{\mathrm{is}}+\mathrm{C}_{\mathrm{jw}} \mathrm{V}_{\mathrm{w}} \eta
$$

In the figure $1_{\mathrm{i}}(\mathrm{t})\left(\mathrm{mBqcm}^{-2}\right)$ represents the inventory of the pollutant $\mathrm{i}$ in the saturated soil. However, in the following $I_{i}(t)$ is represented by $I_{i}$. The material or more appropriately the activity balance equation for the pollutant $\mathrm{i}$ in the volume $\mathrm{V}_{\mathrm{s}}$ was first reported by Joshi and Shukla et. al [3] and subsequently flux component was introduced in the equation by by Shukla can be written as follows

$$
\begin{gathered}
\mathrm{d} / \mathrm{dt}\left(\mathrm{C}_{\mathrm{is}} \mathrm{V}_{\mathrm{s}}\left((1-\phi)+\phi \mathrm{C}_{\mathrm{iw}} \mathrm{V}_{\mathrm{s}}\right)=\left[\mathrm{F}_{\mathrm{i}}(\mathrm{t})-\lambda_{\mathrm{i}}\left\{\mathrm{C}_{\mathrm{is}} \mathrm{V}_{\mathrm{s}}\left((1-\phi)+\phi \mathrm{C}_{\mathrm{iw}} \mathrm{V}_{\mathrm{s}}\right\}\right.\right.\right. \\
\left.-\mathrm{C}_{\mathrm{iw}} \mathrm{V}_{\mathrm{w}} \eta-\mathrm{C}_{\mathrm{is}}(1-\phi) \mathrm{Ec}-\mathrm{J}_{\mathrm{i}}(0, \mathrm{t})\right] \\
\mathrm{C}_{\mathrm{is}} \mathrm{V}_{\mathrm{s}}(1-\phi)+\phi \mathrm{C}_{\mathrm{iw}} \mathrm{V}_{\mathrm{s}}=\mathrm{I}_{\mathrm{i}} \\
\mathrm{C}_{\mathrm{is}} / \mathrm{C}_{\mathrm{jw}}=\mathrm{Kd}_{\mathrm{i}} \\
1+[(1-\phi) / \phi] \mathrm{kd}=\mathrm{R}_{\mathrm{i}} \\
\mathrm{V}_{\mathrm{s}} / \mathrm{V}_{\mathrm{w}}=\beta
\end{gathered}
$$

The equation (4) can be written as; [1]

$$
\begin{aligned}
\mathrm{dI}_{\mathrm{i}} / \mathrm{dt}= & \mathrm{F}_{\mathrm{i}}(\mathrm{t})--\mathrm{I}_{\mathrm{i}}\left[\lambda_{\mathrm{i}}+\left(\eta / \beta \phi \mathrm{R}_{\mathrm{i}}\right)+\left(\mathrm{K}^{\prime} \mathrm{d}_{\mathrm{i}}(1-\phi) \mathrm{Ec}\right) /\left(\phi \quad \beta \mathrm{R}_{\mathrm{i}} \mathrm{V}_{\mathrm{w}}\right)\right. \\
& \left.+\mathrm{J}_{\mathrm{i}}(0, t) /\left(\beta \phi \mathrm{R}_{\mathrm{i}} \mathrm{C}_{\mathrm{iw}} \mathrm{V}_{\mathrm{w}}\right)\right]
\end{aligned}
$$

The present definition of $\beta$ is independent of the soil radionuclides as $\mathrm{V}_{\mathrm{s}}$ depends solely on the quantity of watershed soil and rainfall, but independent of the transport properties of the radionuclide. The varying presentation depth of radionuclide in the watershed soil are now accounted for by their varying diffusion advection flux $\mathrm{Jj}(0, \mathrm{t})$

The inventory in the saturated soil $\mathrm{I}_{\mathrm{i}}$ from 5 and 6 can be written as

$$
\mathbf{I}_{\mathrm{i}}=\phi \mathrm{R}_{\mathrm{i}} \mathrm{C}_{\mathrm{iw}} \beta \mathrm{V}_{\mathrm{w}}
$$

For radionuclides ${ }^{210} \mathrm{~Pb}$ that have constant flux on watershed, steady state can be assumed. Moreover these naturally delivered radionuclides have been falling on watershed since very long time i.e. $\mathrm{t} \rightarrow \infty$ can also be assumed. Under these condition $\mathrm{dI}_{\mathrm{i}} / \mathrm{dt}=0, \mathrm{t} \rightarrow \infty$

$$
\begin{aligned}
\mathrm{F}_{\mathrm{iac}} & =\text { constant atmospheric flux } \\
& =\mathrm{I}_{\mathrm{i}}\left[\lambda_{\mathrm{i}}+\left(\eta / \beta \phi \mathrm{R}_{\mathrm{i}}\right)+\left(\mathrm{K}^{\prime} \mathrm{d}_{\mathrm{i}}(1-\phi) \mathrm{Ec}\right) /\left(\phi \beta \mathrm{R}_{\mathrm{i}} \mathrm{V}_{\mathrm{w}}\right)+1 / \beta \mathrm{V}_{\mathrm{w}}\left(\sqrt{ } \mathrm{D}_{\mathrm{i}} \propto+\mathrm{V}_{\mathrm{i}} / 2\right)\right]
\end{aligned}
$$

Where $F_{\text {iac }}=$ constant atmospheric flux $\left(\mathrm{mBq} \mathrm{cm}^{-2} \mathrm{y}^{-1}\right)$ of the radionuclide $\mathrm{i}$ on the watershed. $\propto$ is defined as $\lambda_{i}+V_{i}^{2} / 4 D_{i}$ where $\mathrm{Vi}$ is the ratio of average pore water velocity and diffusion coefficient of particular nuclide in pore water in $\mathrm{cm}^{2} \mathrm{yr}^{-1}$. Equation (3) can also be written in terms of $\mathrm{I}_{\mathrm{s}}$ and $\beta$ as follows

$$
\operatorname{Fir}(\mathrm{t})=\mathrm{I}_{\mathrm{i}}\left[\left(\eta / \beta \phi \mathrm{R}_{\mathrm{i}}\right)+\mathrm{K}^{\prime} \mathrm{d}_{i}(1-\phi) \mathrm{Ec} /\left(\phi \beta \mathrm{R}_{i} \mathrm{~V}_{\mathrm{w}}\right)\right]
$$

The $\beta$ and Ec can be known by considering ${ }^{210} \mathrm{~Pb}$ radionuclides. Analogous to radioactive branching decay constant, two removals constant for the pollutant inventory in the saturated soil of the watershed can be defined with reference to equation (11) as follows

Catchments removal constant by dissolution

$$
\mathrm{K}_{\mathrm{iwRCD}}=\eta / \beta \phi \mathrm{R}_{\mathrm{i}}
$$


Catchments removal constant by soil erosion $\mathrm{K}_{\mathrm{iwrc}}$

$$
\mathrm{K}_{\mathrm{iwrc}}=\left[\mathrm{Kd}_{\mathrm{i}} \mathrm{Ec}(1-\phi)\right] /\left[\beta \phi \mathrm{R}_{\mathrm{i}} \mathrm{V}_{\mathrm{w}}\right]
$$

The watershed or catchments area removal constants depend both on the catchments and radionuclide properties. In the case of Nagarjuna Sagar Dam Ec can be calculated from three methods namely in present study ${ }^{137} \mathrm{Cs}$ analysis of soil and establishing the relationship between ${ }^{137} \mathrm{Cs}$ lost from the soil verses soil erosion. Second method is direct measurement of soil erosion by collecting soil associated with run off from land and thirdly from the measurement of annual sediment load to the dam.

\section{RESULT AND DISCUSSION}

The estimation of ${ }^{210} \mathrm{~Pb}$ in core samples was carried out to get information on the sedimentation rate in various zones. Figure 1 shows the semi $\log$ plot of excess ${ }^{210} \mathrm{~Pb}$ activity versus depth of core segment samples collected at Lambarpur side of the Bay. The slope of semi log plot was used for computation of sedimentation rate [10]. The sedimentation rate in all the cores was measured and was found $0.4 \mathrm{~cm} / \mathrm{y}$. The deposition of soil entering the dam at Pedaguttu and Lambarpur side of the water reservoir were calculated considering the sediment rate and bulk density and found to be $0.24 \mathrm{~g} \mathrm{~cm}-2 \mathrm{y}-1$.

The $\beta$ in the model is related to $\mathrm{Vs}$ which is the volume of the saturated soil. The concentration and the amount of the high $\mathrm{Kd}$ radionuclide e.g. $\mathrm{Pb}, \mathrm{Zn}, \mathrm{Pu}$ are expected to be high and uniform in the $\mathrm{Vs}$ therefore the depth profile of these elements in the soil gives an insight into the approximate value of $\beta$. The data on industrial $\mathrm{Pb}$ profile in soil clearly show that $85 \%$ of the $\mathrm{Pb}$ is within $1 \mathrm{~cm}$ of top soil till all radionuclide is homogeneously distributed independent to their $\mathrm{Kd}$ and Di therefore depth is decided by the radionuclide having high Kdi and lowest $\mathrm{Di}$ [6]. Based on Pb profile in soil depth can be taken as $1 \mathrm{~cm}$. The Nagarjuna sagar has low rainfall. $1000 \mathrm{~mm}$ rain fall was taken in this calculation based on the earlier report. Therefore expected value of $\beta$ is $\mathrm{Vs} / \mathrm{Vw}$ or $1 / 100$ (year). The average density of dry soil down to a depth of 2 inch was $1.1 \mathrm{gcm}^{-3}$ which yield the porosity of 0.51 . The porosity was calculated as per the standard procedure. Dominik et.al [9] have reported the $\mathrm{K}_{\mathrm{dpb}}=1 \times 10^{5} \mathrm{ccg}^{-1}$. In the distribution coefficient model Joshi and Shukla [1] has used a value of $1.9 \times 10^{5} \mathrm{cc} \mathrm{g}^{-1}$. Based on the partitioning of ${ }^{210} \mathrm{~Pb}$ between river water and suspended sediment.

Ec, soil erosion rate was calculated from annual suspended sediment silt load of the dam. The annual sediment silt load of the dam comes to $2.4 \mathrm{Kg} \mathrm{m}^{-2} \mathrm{y}^{-1}$ in Pedaguttu and Lambarpur. Considering the area of $285 \mathrm{~km}^{2}$ of Nagarjuna Sagar dam and a catchments area of $215185 \mathrm{~km}^{2}$ soil erosion rate comes to $2.4 \times 10^{-4} \mathrm{~cm} \mathrm{y}^{-1}$. The measurement and data analysis of the suspended sediment for seven rivers in Ontario, Canada by Dickinson et.al. 1975 have indicated that range of annual soil erosion rate in southern Ontario lies between $5.25 \times 10^{-3}$ and $1.7 \times 10^{-1} \mathrm{~kg} \mathrm{~m}^{-2} \mathrm{y}^{-1}$. By considering the suspended sediment load in the water it is concluded that Ec value found in the range of 0.287 to $7.0 \times 10^{-4} \mathrm{Kg} \mathrm{m}^{-2}$ year $^{-1}$ in the Rhone watershed in Canada. The data on industrial $\mathrm{Pb}$ profile in soil clearly show that $85 \%$ of $\mathrm{Pb}$ is within $1 \mathrm{~cm}$ of top soil and no industrial $\mathrm{Pb}$ below $2 \mathrm{~cm}$ [6]. It is important to reiterate that $\mathrm{V}_{\mathrm{s}}\left(\mathrm{cm}^{3} / \mathrm{cm}^{2}\right)$ is the theoretical depth in the soil till which all radionuclides are homogeneously distributed independent to their $\mathrm{K}_{\mathrm{di}}$ or $\mathrm{D}_{\mathrm{i}}$. Since $\mathrm{Kd}_{\mathrm{i}}$ of $\mathrm{Pb}$ will decide the $\mathrm{V}_{\mathrm{s}}$ of the soil. Based on the $\mathrm{Pb}$ profile in the soil $\mathrm{V}_{\mathrm{s}}$ can be taken as $1 \mathrm{~cm} . \mathrm{R}_{\mathrm{i}}$ is the retardation factor defined as

$$
\mathrm{R}_{\mathrm{i}}=1+[\rho(1-\phi) / \phi] \mathrm{kd}_{\mathrm{i}}
$$

$\rho$ is the density of the dry sediment particle $\mathrm{gm} / \mathrm{cm}^{3}=2.65$

$\phi=$ Porosity of the sediment (Dimensionless) 0.510

$\mathrm{Kd}_{\mathrm{i}}=$ adsorption desorption partition coefficient $1.9 \times 10^{5} \mathrm{~cm}^{-3} \mathrm{~g}^{-1}$.

$\mathrm{R}_{\mathrm{i}}=$ was calculated and found to be $4.83 \times 10^{5}$

$\mathrm{Ec}=$ soil erosion rate $2.39 \times 10^{-4} \mathrm{~cm} / \mathrm{y}$. 
Based on these values $\mathrm{K}_{\mathrm{iwrc}}=1.9 \times 10^{5} \times 2.39 \times 10^{-4} \times 0.490 / 1.6 \times 106 \times 10^{-2} \times 100 \times 0.51=$ $0.24 \times 10^{-4}$

Therefore residence time $=1 / 0.24 \times 10^{-4}=4166 \mathrm{y}$

The residence time calculated from some famous catchment are shown in the Table 1 below

Table 1. Transport parameter of some famous catchments.

\begin{tabular}{|c|c|c|c|c|}
\hline S.N. & Catchments & $\begin{array}{c}\text { Transport } \\
\text { coefficient }\left(\mathrm{yr}^{-1}\right)\end{array}$ & $\begin{array}{c}\text { Residence Time } \\
(\text { year })\end{array}$ & Reference \\
\hline 1 & Mississipi & 0.00039 & 2580 & {$[14]$} \\
\hline 2 & Alpine Rhone & 0.000072 & 1400 & {$[10]$} \\
\hline $\mathbf{3}$ & Nagarjun Sagar Dam water reservoir & $\mathbf{0 . 0 0 0 0 2 7}$ & $\mathbf{4 1 6 6}$ & Present study \\
\hline
\end{tabular}

\section{CONCLUSION}

The behavior of ${ }^{210} \mathrm{~Pb}$ from natural sources in the soil surface water system provide the most direct information on the kinetics of process involving Heavy metals from natural and man made sources. Particle active nature of the ${ }^{210} \mathrm{~Pb}$ is applied to derive soil erosion rate and residence time. A low transport coefficient and high residence time of the particle active metals in the catchments of the Nagarjuna Sagar Dam was observed. A comparison was the residence time in the catchments of Susquehanna, Mississipi and Alpine Rhone was made and higher value was obtained. Results clearly demonstrate the importance of $\beta$ and $\mathrm{K}_{\mathrm{d}}$ (distribution coefficient) on deciding the transport of pollutant from catchments to Dam A residence time of 4166 year was observed in the Pedaguttu and Lambarpur side of the water reservoir. A higher residence time can be due to low rainfall in that area. Using the same technique a residence time of 3000 years was calculated in the watershed of the Saguenay River in Canada.

\section{References}

[1] B.S.Shukla; Watershedriver and lake modeling through environmental radioactivity, Environmental research and publications Inc, Hamilton, Ontario, Canada, (1993).

[2] B. S. Shukla, Sedimentation rate through environmental radioactivity (Models and Applications), Environmental Research Publication INC, 2002

[3] Carpenter R, Peterson M.L, Bennett J.T. ${ }^{210} \mathrm{~Pb}$ derived sediment accumulation and mixing rates for Washington continental slope, Mar. Geol., 48, (1982), pp. 135-164.

[4] Dale M. Lewis, The use of $210 \mathrm{~Pb}$ as a heavy metal tracer in the Susquehanna river system. Cosmochimica Acta, Vol 41, (1977), 1557-1564

[5] Environmental Impact Assessment and Environmental Management Plan on LambarpurPedaguttu Uranium mining project- UCIL, March 2003.

[6] Erel Y., Patterson, C. C., Scott, M. J., and Morgan, J.J. Transport of industrial lead in snow though soil to stream water and ground water. Chemical Geol., 85, (1990), 383-392

[7] Jha, S.K., Chavan, S.B., Pandit, G.G., Negi, B.S., Sadasivan, S., Behavior \& fluxes of trace and toxic elements in creek sediment near Mumbai, India. Environmental Monitoring and Assessment 76, (2002), 249-262.

[8] Jha S.K, Krishnamoorthy T.M, Pandit G.G, Nambi K.S.V. History of accumulation of mercury and nickel in Thane Creek, Mumbai using $210 \mathrm{~Pb}$ dating technique. Science of the Total Environment, 236, (1999), pp. 91-99.

[9] J. Dominik, D. Berrus, J. P. Vernet, Transport of the environmental radionuclides in an alpine watershed, Earth and Planetary Science Leteers, 84 (1987) 165-180

[10] Krishnaswami S, Lal D, Radionuclide alimnochronology, in 'Lakes, Chemistry, Geology, Physics' Ed. A. Lerman (Springer Verlag, NewYork), (1978), pp. 153-177.

[11] Scott M. R., R. J. Rotter, P. F. Salter, Transport of fallout Plutonium to the ocean by the Mississippi River., Planetory Science Letter 75, (1985), 321-326 